\title{
Race vs belief as determinants of attraction in a group interaction context*
}

\author{
CLYDE HENDRICK, C. SCULLY STIKES, EDWARD J. MURRAY, and CAROL PUTHOFF \\ Kent State University, Kent, Ohio 44242
}

\begin{abstract}
Three experiments which tested the effects of race vs belief similarity as determinants of prejudiced responding in a live interaction situation are reported. Two black and two white confederates engaged a white $S$ in a discussion of an issue (ROTC in Experiments I and II and abortion in III). One white and one black confederate agreed with the S's position and the other pair disagreed. Ss then rated all four confederates on a variety of scales. Results showed strong belief effects in all three experiments but very few race effects. A few measures showed a "renegade effect" against dissimilar white confederates. It was concluded that simply increasing the power and realism of the experimental situation does not in any important way increase the number of racially prejudiced responses. Some conditions which may elicit strong and consistent race prejudice effects are discussed.
\end{abstract}

Numerous studies have tested the theory proposed by Rokeach, Smith. and Evans (1960) that belief similarity-dissimilarity is a stronger determinant of discriminative evaluative reactions than racial or ethnic membership. Most of this research has supported the theory, although it is subject to a variety of criticisms. Typical procedures involve presenting questionnaires to Ss which were purportedly completed by a stranger. The stranger is similar or dissimilar to the $S$ in some set of beliefs, and his racial membership is varied (usually black and white). This paper-and-pencil approach is not very powerful and may not be realistic (Sears \& Abeles, 1969 , p. 273). It also allows controversy concerning the relative strength of race and belief manipulations (Byrne. 1969; Rokeach, 1961; Triandis, 1961).

Rokeach and Mezei (1966) attempted to overcome some of these difficulties by having two black and two white confederates engage a $\mathrm{S}$ in a discussion, after which the $\mathrm{S}$ chose two of the confederates as partners for a coffee break (in two experiments) or as work partners (in a third experiment). Results showed that choices were made on the basis of belief similarity. Unfortunately, the results of this interesting study were marred by the possible reactive nature of the dependent measure (Campbell. 1969, p. 374). Fear of being labeled as racist may have prevented Ss from choosing on the basis of race even if they had actually desired to do so.

Hendrick, Bixenstine, and Hawkins (1971) attempted to solve the reactive measurement problem by presenting video-taped interaction of four actors and obtaining private evaluations from $S s$ for each actor. The results showed strong belief effects but few race effects. In written comments. several $S s$ indicated that the experiment would have been more interesting and involving if the interaction had been presented live.

*This research was supported by Grant MH 18652-01 from the National Institute of Mental Health to the first author.
Following upon this suggestion, Hendrick, Stikes, and Murray (in press) had Ss observe two black and two white confederates discussing an issue in person. However, once again only belief effects were obtained.

The lack of race effects in this area of research is an anomaly in view of the strong racial and ethnic hostility that exists in this country. At the same time, the race vs belief issue is very important with respect to social implications. If belief discrimination is the important variable determining discriminatory reactions and if racial membership per se is not very important (as the research suggests), then direct implications may be drawn concerning methods to ameliorate racial antagonisms. However, such inferences require that race effects per se do not exist, and the suspicion lingers that lack of such effects in the experiments may be due to procedural problems rather than reflecting substantive social reality.

It may well be that previous research has suffered from lack of ego involvement on the part of the $S$. who is generally a detached observer. In Aronson and Carlsmith's (1968) terminology, this area of research might benefit from strong event manipulations. Elicitation of racially prejudiced reactions may require strong personal involvement on the part of the Ss, as in Rokeach and Mezei's (1966) group discussion procedure. Secondly, because of the strong norms against showing overt prejudice, the measurement procedure must not be reactive (i.e.. it must not have a built-in bias that prevents Ss from making racially discriminatory responses).

Three experiments are reported which pursued this line of reasoning. Groups of five people engaged in a small group discussion on a specific issue. In actual fact. four of the people were confederates. Two confederates were black and two were white. One black and one white confederate always agreed with the $S^{\prime}$ 's belief position and the other pair disagreed. After the group 
discussion, the five persons rated each other privately on several scales. To ensure generality of the findings, two experiments were conducted with males on one issue and the third experiment was conducted with females on a different issue.

\section{METHOD}

The general procedures were similar for all three experiments and are described below with differences between experiments noted as appropriate.

\section{General Procedure}

The Ss were members of an introductory psychology course recruited via telephone to participate in a group discussion experiment. Ss reported to a room in the campus library which had the sign "Small Group Discussion" attached to the door. Ss were greeted by a moderator and asked to wait until all Ss arrived. Ostensibly, five $S s$ reported for the group discussion. In actual fact, four of these Ss were confederates, two of which were black and two were white. The confederates arrived individually over a period of several minutes. The moderator obtained the names of everyone present, gave them name tags, and asked them to be seated. The seating arrangement was controlled as noted below. The moderator introduced the study as an experiment in person perception. He explained that the group would discuss an issue for about $20 \mathrm{~min}$, during which they would form impressions of each other, and afterwards evaluate each other on several scales. After this introduction, the discussion followed. One black and one white confederate agreed with the S's position on the issue and the other pair disagreed. After the discussion, the five discussants were separated to make the ratings. The confederates went through the motions of making the ratings to maintain the credibility of the experiment.

\section{Subjects and Issues}

Male Ss served in Experiments I and II, and females served in Experiment III. The confederates and the moderator were always the same sex as the S. The belief issue was "ROTC on campus" in the first two experiments and "viewpoints on abortion" in the third experiment. Ss were recruited for the experiments based on their responses to a comprehensive attitude questionnaire administered to several hundred introductory psychology students at the beginning of the quarter. Several items pertained to a given issue. Ss both pro and con on the relevant issue were recruited.

The design of the experiment was partially based on seating arrangements as noted below. Eight $S$ s were required to satisfy the design that was replicated. Thus, $16 \mathrm{Ss}$ served in each of the three experiments. In each experiment, $8 \mathrm{Ss}$ were pro on the issue and 8 were anti (ROTC in Experiments I and II and abortion in III). Although only Ss who expressed relatively firm opinions on the issue were recruited, during the course of the experiment a few Ss showed attitudes discrepant from their initial positions or they expressed inconsistent attitudes during the discussion. These Ss were replaced by other Ss. There were 3 such Ss in Experiment I, 5 in II, and none in III.

\section{Confederates $^{1}$}

The confederates were graduate and undergraduate students in psychology and sociology. Several hours were spent rehearsing arguments pro and con on the issues. For the male confederates in Experiments I and II, a 44-page position paper on ROTC recently prepared by the Dean's office for the faculty was used to derive relevant arguments and counterarguments. For female confederates in Experiment III, arguments on the abortion issue were derived from various books and pamphlets. Confederates rehearsed until they were equally facile in taking both pro and con roles on the issue. Since the facade of spontaneous discussion was desired in the experiments: training of the confederates was quite important. The results of the studies indicated that the confederates played their roles exceptionally well.

\section{Seating Arrangement}

The chairs for the five discussants were arranged in a semicircle about $1 \mathrm{ft}$ apart. The moderator sat facing the group about $8 \mathrm{ft}$ from them. The $S$ was always placed in the middle seat, and he always sat between one black and one white confederate. These two confederates expressed beliefs dissimilar to the S's beliefs, while the confederates seated on each end of the semicircle expressed similar beliefs. The semicircular arrangement allowed the $S$ to have eye contact with the similar confederates, thus obtaining a measure of social support from them.

The white and black actors were designated $W_{1}, W_{2}, B_{1}$, and $B_{2}$, respectively. Based on observation of the confederates' training sessions, $W_{1}$ and $B_{2}$ were always paired with each other to take the same position on the issue and $W_{2}$ and $B_{1}$ took the opposing position. As noted above, seating arrangements for expression of opinions relative to the $S$ were fixed. From left to right, facing the seated group, these positions were: similar, dissimilar, S, dissimilar, similar. For different Ss, pairs of actors were rotated across seats in four basic permutations (from left to right facing the group): $B_{1} W_{1} S_{1} B_{2} W_{2} ; B_{2} W_{2} S_{2} B_{1} W_{1} ; W_{1}$ $B_{1} S_{3} W_{2} B_{2} ; W_{2} B_{2} S_{4} W_{1} B_{1}$. This rotation ensured that each confederate sat in each of the four available seats. At the same time, the roles of agree-disagree with the $S$ were balanced across confederates. This design also kept one similar and dissimilar actor on each side of the $S$ and one black and one white immediately adjacent to him.

Four Ss with a given belief position (e.g., pro-ROTC) were required for the four seating arrangements. The same four arrangements were used for four other $S$ s with the opposite belief position (e.g., anti-ROTC). A set of eight such Ss was considered as one stimulus replication. Two such replications were used in each experiment. The experimental control was sufficiently precise so that the replications factor was significant on very few measures, and it is disregarded in the remainder of this report.

\section{Procedure}

The moderator arrived a few minutes early to arrange the chairs and materials. After the group had arrived, they were given name tags. The moderator then made a few remarks about experimental control and said that seating order would be determined randomly. A phony drawing of - lots for seat assignments was held so that the $S$ thought he was assigned the middle seat by chance.

After the group was properly seated, the $E$ introduced the study as an experiment on person perception. The purpose of the discussion was to give the group a chance to know and form impressions of each other. A somewhat controversial topic was chosen to stimulate the discussion. The ratings that would be made after the discussion were mentioned briefly at this point.

After his introduction, the moderator gave the group a couple of minutes to collect their thoughts. Then each of the five discussants was asked to take a minute to present his views on the issue. Afterwards, discussion was open and was allowed to continue for about $15 \mathrm{~min}$. During this discussion phase, the confederates moderated their performances appropriately, and it was seldom necessary for the moderator to say anything.

One variable of potential importance was the order in which the group members expressed their initial position on the issue. 
Table 1

Means for Perceived Similarity

\begin{tabular}{|c|c|c|c|c|c|c|c|c|c|}
\hline \multirow{3}{*}{$\begin{array}{l}\text { Type } \\
\text { of Ss }\end{array}$} & \multirow{3}{*}{$\begin{array}{l}\text { Actors' } \\
\text { Race }\end{array}$} & \multirow{2}{*}{\multicolumn{2}{|c|}{$\begin{array}{c}\begin{array}{c}\text { Experiment I } \\
\text { (Males) }\end{array} \\
\text { Actors' Belief }\end{array}$}} & \multirow{2}{*}{\multicolumn{2}{|c|}{$\begin{array}{c}\begin{array}{c}\text { Experiment Il } \\
\text { (Males) }\end{array} \\
\text { Actors' Belief }\end{array}$}} & \multirow{3}{*}{$\begin{array}{l}\text { Type } \\
\text { of Ss }\end{array}$} & \multirow{3}{*}{$\begin{array}{c}\text { Actors' } \\
\text { Race }\end{array}$} & \multirow{2}{*}{\multicolumn{2}{|c|}{$\begin{array}{c}\begin{array}{c}\text { Experiment III } \\
\text { (Females) }\end{array} \\
\text { Actors' Belief } \\
\end{array}$}} \\
\hline & & & & & & & & & \\
\hline & & Similar & Dissimilar & Similar & Dissimilar & & & Similar & Dissimilar \\
\hline $\begin{array}{l}\text { Anti- } \\
\text { ROTC }\end{array}$ & $\begin{array}{l}\text { White } \\
\text { Black }\end{array}$ & $\begin{array}{l}8.00 \\
7.88\end{array}$ & $\begin{array}{l}2.25 \\
2.88\end{array}$ & $\begin{array}{l}7.88 \\
8.25\end{array}$ & $\begin{array}{l}1.38 \\
2.13\end{array}$ & $\begin{array}{l}\text { Anti- } \\
\text { Abortion }\end{array}$ & $\begin{array}{l}\text { White } \\
\text { Black }\end{array}$ & $\begin{array}{l}8.88 \\
8.75\end{array}$ & $\begin{array}{l}1.00 \\
1.13\end{array}$ \\
\hline $\begin{array}{l}\text { Pro- } \\
\text { ROTC }\end{array}$ & $\begin{array}{l}\text { White } \\
\text { Black }\end{array}$ & $\begin{array}{l}8.75 \\
8.38\end{array}$ & $\begin{array}{l}1.63 \\
1.75\end{array}$ & $\begin{array}{l}8.25 \\
8.25\end{array}$ & $\begin{array}{l}1.50 \\
2.88\end{array}$ & $\begin{array}{l}\text { Pro- } \\
\text { Abortion }\end{array}$ & $\begin{array}{l}\text { White } \\
\text { Black }\end{array}$ & $\begin{array}{l}9.00 \\
9.00\end{array}$ & $\begin{array}{l}1.00 \\
1.00\end{array}$ \\
\hline
\end{tabular}

Note-Each mean is based on eight Ss.

In Experiment I and the first replication of Experiment II, the moderator simply called on the group members from left to right to make their initial statements. However, this procedure was changed for the second replication of Experiment II and all of Experiment III so that the actual S was called upon first to present his position, followed by the confederate's statements from left to right. The moderator indicated by checking a slip of paper that the order of initial speaking had been randomly determined. Having the $S$ speak first enabled the confederates to tailor their arguments to agree or disagree with the $S$ in a much more precise manner.

The tenor of the discussion was varied across the three experiments. In Experiment 1 , there was debate and argument but it was always conducted at a "gentlemanly" level. In Experiment II, the same discussion format was maintained for the first replication. but during the second replication a much more intense discussion was allowed. Confederates were allowed to ridicule each other and argue strenuously with the $\mathrm{S}$, with the proviso that no profanity was used. Another change in Experiment II was that some raciaily relevant arguments were introduced, primarily by black but occasionally by white confederates. The arguments were personalistic in nature (e.g. why ROTC is bad for me as a black), and they were always subordinated to the main substantive issue, ROTC on campus. The intense discussion format was also used in Experiment III for the abortion issue. The sessions in the second replication of Experiment II and all of III were deemed to be powerful and emotionally intense.

After about $15 \mathrm{~min}$. the moderator stopped the discussion and introduced the rating form, the Interpersonal Perception Questionnaire. The five group members were directed to various corners and the center of the room to make their ratings. Confederates always filled out the rating booklet. taking as much time as the actual S. Each booklet contained three pages of ratings for each confederate. The first page included five questions designed to assess liking, perceived belief similarity, and perceptions of clearness. value, and dominance of the ratee's discussion. The second page included eight trait ratings. and the third page included eight social distance items. Each item was rated on a 9-point scale with values from -4 to +4 (which were transformed to a 1- to 9-point basis for ease of computation). The endpoints (and midpoints of the traits) were appropriately labeled (e.g., like very' much, dislike very much).

The $S$ rated the four confederates in an order from left to right (from the moderator's perspective). The name of the confederate was written in a slot at the top of each page. Further distinctiveness, was achieved by alternating the color of the booklet pages between white and red for different confederates. The last page of the booklet contained several belief items on the issue identical to those used to preselect the $S$ s for the experiment

After the ratings were completed, the moderator talked to the group a few minutes. swore them to silence. and dismissed them. Ss were not debriefed at this point. It was felt that this situation was one in which disclosure of the deception would do more harm than good (Campbell, 1969, p. 371). Disclosure of such deception by no less than five other people immediately following such an intense discussion was likely to be very ego deflating. Instead, the senior investigator invited the Ss via letter to return a few weeks later for a discussion of the experiment. Unfortunately, very few did return. However, with respect to the Ss' welfare, both written and oral comments indicated that they found the discussion a highly enjoyable and valuable experience. Their only complaint was that the discussion was stopped too soon.

\section{RESULTS}

The rating data for each question were subjected to an analysis of variance. The results for each experiment are presented in terms of 2 by 2 by 2 analyses with S's position (pro-con) as a between-S variable and race of the actors and positions of the actors relative to $\mathrm{Ss}$ (similar-dissimilar) as within-S variables. For economy of space, comprehensive analysis of variance tables are omitted in favor of selective presentation and discussion of relevant effects. The results are presented under three general categories: perception of similarity, belief effects, and race effects.

\section{Perception of Similarity}

The question "To what extent do you agree with the position of this person on the issue?" served as a check on the manipulation of perceived similarity to the confederates. The means for this check are shown in Table 1 for the three experiments. Inspection of the table indicates that the manipulation was highly successful in all three experiments. Similar confederates were rated around 8.0 or better (with 9.0 the maximum possible), and dissimilar confederates were rated less than 3.0. The analyses of variance confirmed the success of the manipulations. The main effect of $\mathrm{Ss}^{\circ}$ similarity-dissimilarity to the actors was significant in all the experiments. The $F$ ratios were: Experiment 1 . 436.6: Experiment II, 170.9: Experiment III, 13.891.5 ( $d f=1 / 14$ for each experiment). The unusual $F$ ratio for the third experiment was due to the fact that every similarity rating of the eight pro-abortion females was perfectly and maximally extreme. and the same was almost true of the anti-abortion females. 
Table 2

Mean. Ratings: Similarity by Race of Actor

\begin{tabular}{|c|c|c|c|c|c|c|c|}
\hline & \multirow{2}{*}{$\begin{array}{c}\text { Experi- } \\
\text { ment }\end{array}$} & \multicolumn{3}{|c|}{ Similar Actors } & \multicolumn{3}{|c|}{ Dissimilar Actors } \\
\hline & & White & Black & Mean & White & Black & Mean \\
\hline \multicolumn{8}{|l|}{ Measure } \\
\hline Liking & $\begin{array}{l}\text { I } \\
\text { II } \\
\text { III* }\end{array}$ & $\begin{array}{l}7.06 \\
7.69 \\
8.13\end{array}$ & $\begin{array}{l}7.44 \\
7.81 \\
7.94\end{array}$ & $\begin{array}{l}7.25 \\
7.75 \\
8.03\end{array}$ & $\begin{array}{l}6.00 \\
4.75 \\
4.38\end{array}$ & $\begin{array}{l}6.25 \\
5.50 \\
5.69\end{array}$ & $\begin{array}{l}6.13 \\
5.13 \\
5.03\end{array}$ \\
\hline $\begin{array}{l}\text { Dominated } \\
\text { Discussion }\end{array}$ & $\begin{array}{l}1 \\
\text { II } \\
\text { III }\end{array}$ & $\begin{array}{l}7.00 \\
6.50 \\
6.94\end{array}$ & $\begin{array}{l}6.25 \\
5.81 \\
6.13\end{array}$ & $\begin{array}{l}6.63 \\
6.16 \\
6.53\end{array}$ & $\begin{array}{l}7.25 \\
6.69 \\
7.25\end{array}$ & $\begin{array}{l}6.44 \\
6.19 \\
6.25\end{array}$ & $\begin{array}{l}6.84 \\
6.44 \\
6.75\end{array}$ \\
\hline $\begin{array}{l}\text { Value of } \\
\text { Contribution }\end{array}$ & $\begin{array}{l}\text { I } \\
\text { II } \\
\text { III }\end{array}$ & $\begin{array}{l}7.63 \\
7.69 \\
7.81\end{array}$ & $\begin{array}{l}6.88 \\
7.56 \\
7.31\end{array}$ & $\begin{array}{l}7.25 \\
7.63 \\
7.56\end{array}$ & $\begin{array}{l}6.81 \\
6.50 \\
6.50\end{array}$ & $\begin{array}{l}6.50 \\
5.63 \\
6.44\end{array}$ & $\begin{array}{l}6.66 \\
6.06 \\
6.47\end{array}$ \\
\hline $\begin{array}{l}\text { Presented } \\
\text { Clearly }\end{array}$ & $\begin{array}{l}\text { I } \\
\text { II } \\
\text { III }\end{array}$ & $\begin{array}{l}8.13 \\
7.63 \\
8.06\end{array}$ & $\begin{array}{l}7.25 \\
7.06 \\
8.25\end{array}$ & $\begin{array}{l}7.69 \\
7.34 \\
8.16\end{array}$ & $\begin{array}{l}7.25 \\
6.19 \\
7.06\end{array}$ & $\begin{array}{l}7.13 \\
5.94 \\
6.81\end{array}$ & $\begin{array}{l}7.19 \\
6.06 \\
6.94\end{array}$ \\
\hline \multicolumn{8}{|l|}{ Traits } \\
\hline Opinio & $\begin{array}{l}\text { I } \\
\text { II } \\
\text { III }\end{array}$ & $\begin{array}{l}7.38 \\
7.25 \\
7.69\end{array}$ & $\begin{array}{l}6.88 \\
6.56 \\
7.13\end{array}$ & $\begin{array}{l}7.13 \\
7.44 \\
7.41\end{array}$ & $\begin{array}{l}6.88 \\
7.00 \\
8.19\end{array}$ & $\begin{array}{l}6.38 \\
6.88 \\
7.06\end{array}$ & $\begin{array}{l}6.63 \\
6.56 \\
7.63\end{array}$ \\
\hline Inte & $\begin{array}{l}\text { I } \\
\text { II } \\
\text { III }\end{array}$ & $\begin{array}{l}6.88 \\
7.63 \\
7.56\end{array}$ & $\begin{array}{l}6.75 \\
7.00 \\
7.25\end{array}$ & $\begin{array}{l}6.81 \\
7.31 \\
7.41\end{array}$ & $\begin{array}{l}7.00 \\
6.69 \\
6.50\end{array}$ & $\begin{array}{l}6.44 \\
5.94 \\
6.38\end{array}$ & $\begin{array}{l}6.72 \\
6.31 \\
6.44\end{array}$ \\
\hline Open-minded & $\begin{array}{l}\text { I } \\
\text { II } \\
\text { III }\end{array}$ & $\begin{array}{l}5.38 \\
6.81 \\
6.63\end{array}$ & $\begin{array}{l}6.38 \\
6.56 \\
6.25\end{array}$ & $\begin{array}{l}5.88 \\
6.69 \\
6.44\end{array}$ & $\begin{array}{l}3.94 \\
2.50 \\
3.25\end{array}$ & $\begin{array}{l}4.56 \\
3.25 \\
3.06\end{array}$ & $\begin{array}{l}4.25 \\
2.88 \\
3.16\end{array}$ \\
\hline Frie & $\begin{array}{l}\text { I } \\
\text { II } \\
\text { III * }\end{array}$ & $\begin{array}{l}6.69 \\
7.63 \\
7.63\end{array}$ & $\begin{array}{l}6.69 \\
6.81 \\
7.50\end{array}$ & $\begin{array}{l}6.69 \\
7.22 \\
7.56\end{array}$ & $\begin{array}{l}6.31 \\
4.94 \\
4.25\end{array}$ & $\begin{array}{l}5.81 \\
5.06 \\
5.88\end{array}$ & $\begin{array}{l}6.06 \\
5.00 \\
5.06\end{array}$ \\
\hline Relaxed & $\begin{array}{l}\text { I } \\
\text { II } \\
\text { III }\end{array}$ & $\begin{array}{l}7.38 \\
6.81 \\
7.31\end{array}$ & $\begin{array}{l}6.94 \\
6.94 \\
7.88\end{array}$ & $\begin{array}{l}7.16 \\
6.88 \\
7.59\end{array}$ & $\begin{array}{l}6.25 \\
5.56 \\
5.75\end{array}$ & $\begin{array}{l}6.13 \\
5.69 \\
7.06\end{array}$ & $\begin{array}{l}6.19 \\
5.63 \\
6.41\end{array}$ \\
\hline Sincere & $\begin{array}{l}\text { I } \\
\text { II } \\
\text { III* }\end{array}$ & $\begin{array}{l}7.88 \\
7.44 \\
8.13\end{array}$ & $\begin{array}{l}7.38 \\
7.44 \\
7.69\end{array}$ & $\begin{array}{l}7.63 \\
7.44 \\
7.91\end{array}$ & $\begin{array}{l}6.63 \\
6.06 \\
5.63\end{array}$ & $\begin{array}{l}6.69 \\
6.44 \\
6.44\end{array}$ & $\begin{array}{l}6.66 \\
6.25 \\
6.03\end{array}$ \\
\hline Informed & $\begin{array}{l}\text { I } \\
\text { II } \\
\text { III }\end{array}$ & $\begin{array}{l}7.25 \\
7.31 \\
7.50\end{array}$ & $\begin{array}{l}6.63 \\
6.88 \\
7.31\end{array}$ & $\begin{array}{l}6.94 \\
7.09 \\
7.41\end{array}$ & $\begin{array}{l}5.56 \\
5.31 \\
4.31\end{array}$ & $\begin{array}{l}5.56 \\
4.81 \\
4.38\end{array}$ & $\begin{array}{l}5.56 \\
5.06 \\
4.34\end{array}$ \\
\hline Courteous & $\begin{array}{l}\text { I } \\
\text { II } \\
\text { III }\end{array}$ & $\begin{array}{l}6.63 \\
6.75 \\
7.44\end{array}$ & $\begin{array}{l}6.75 \\
6.63 \\
8.00\end{array}$ & $\begin{array}{l}6.69 \\
6.69 \\
7.72\end{array}$ & $\begin{array}{l}5.88 \\
4.25 \\
5.00\end{array}$ & $\begin{array}{l}5.75 \\
4.75 \\
5.88\end{array}$ & $\begin{array}{l}5.81 \\
4.50 \\
5.44\end{array}$ \\
\hline
\end{tabular}

Social Distance

$\begin{array}{llllllll}\text { Willing to } & \text { I } & 7.50 & 7.50 & 7.50 & 5.75 & 6.00 & 5.88 \\ \text { Work With } & \text { II } & 7.94 & 8.13 & 8.03 & 5.56 & 6.00 & 5.78 \\ & \text { III } & 8.31 & 8.44 & 8.38 & 4.63 & 4.88 & 4.75 \\ & \text { I } & 7.88 & 7.69 & 7.78 & 6.44 & 6.19 & 6.31 \\ \text { Party With } & \text { II } & 8.13 & 7.88 & 8.00 & 5.50 & 6.19 & 5.84 \\ & \text { III } & 7.81 & 8.06 & 7.94 & 5.63 & 5.38 & 5.50 \\ & \text { I } & 7.19 & 7.44 & 7.31 & 5.75 & 5.81 & 5.78 \\ \text { Invite to } & \text { II* } & 7.75 & 7.75 & 7.75 & 5.25 & 6.25 & 5.75 \\ \text { Dinner } & \text { III* } & 7.88 & 7.56 & 7.72 & 4.31 & 5.38 & 4.84 \\ & \text { I } & 7.75 & 7.50 & 7.63 & 6.31 & 6.00 & 6.16 \\ \text { Live } & \text { II* } & 8.25 & 8.06 & 8.15 & 5.50 & 6.63 & 6.06 \\ \text { Next Door } & \text { III } & 7.81 & 7.44 & 7.63 & 5.63 & 5.69 & 5.66 \\ & \text { I } & 7.75 & 7.69 & 7.72 & 6.06 & 5.88 & 5.97 \\ \text { Belong to } & \text { II* } & 8.13 & 7.69 & 7.91 & 4.75 & 5.88 & 5.31 \\ \text { Same Social } & \text { III } & 7.88 & 7.69 & 7.78 & 4.88 & 5.75 & 5.31 \\ \text { Group } & \text { I } & 7.68 & 7.75 & 7.72 & 5.50 & 5.25 & 5.38 \\ & \text { II* } & 7.81 & 7.69 & 7.75 & 4.25 & 5.25 & 4.75 \\ \text { Share Dorm } & \text { III } & 8.00 & 7.75 & 7.88 & 3.56 & 4.31 & 3.94 \\ \text { Room } & & & & & & & \end{array}$

Table 2 (Continued)

\begin{tabular}{lllllllll}
\hline & & \multicolumn{3}{c}{$\begin{array}{c}\text { Similar Actors } \\
\text { ment }\end{array}$} & & \multicolumn{2}{c}{ Dissimilar Actors } \\
& White & Black & Mean & White & Black & Mean \\
Have as & I & 7.06 & 7.19 & 7.13 & 5.38 & 5.25 & 5.31 \\
Close Friend & II & 7.50 & 7.88 & 7.69 & 4.38 & 4.25 & 4.31 \\
& III & 7.81 & 7.75 & 7.78 & 2.88 & 3.81 & 3.34 \\
Date my & I & 6.75 & 5.63 & 6.19 & 5.19 & 4.44 & 4.81 \\
Sister & II* & 7.06 & 5.50 & 6.28 & 4.13 & 4.50 & 4.31 \\
(Brother) & III & 7.13 & 6.31 & 6.72 & 3.81 & 4.13 & 3.97 \\
\hline
\end{tabular}

Vote-A significant $(.05$ level) interaction is indicated by * next to the appropriate experiment number in the column labeled "Experiment." The $d f=1 / 14$

Only two other effects were significant. In Experiment I, the initial attitude of Ss (pro- or anti-ROTC) interacted with Ss' similarity-dissimilarity to the actors $(F=6.6, d f=1 / 14, p<.05)$. This interaction was due to the fact that the dissimilarity means were slightly more extreme for the pro-ROTC than for the anti-ROTC Ss. The other effect occurred in Experiment II. The main effect of actors' race was significant $(F=5.2, \mathrm{df}=1 / 14, \mathrm{p}<.05)$ and was due to slightly higher similarity ratings for black than for white confederates. It may be concluded that the manipulations of belief were successful. The strength of the effects indicates that a high degree of experimental control was achieved in the discussion situation and with little contamination due to other variables.

\section{Effects of Belief Similarity}

The mean ratings for similar and dissimilar actors are shown in Table 2 for each of the 20 dependent variables in each of the three experiments. Means are shown for both white and black actors and are averaged over race as well. The main effect of belief similarity-dissimilarity tests the difference of the two average scores shown in Columns 3 and 6 . Inspection of these means indicates, and the variance analyses confirmed, many differences due to variation in belief similarity. Similar actors were evaluated more favorably than were dissimilar actors. This effect was significant on 13 of the 20 measures in Experiment I, 18 measures in Experiment II, and 17 measures in Experiment III. In Experiment I, the measures not achieving significance were: dominated discussion, value of contribution, presented clearly, opinionated, intelligent, friendly, and courteous. Of the remaining 13 items which were significant, the $F$ ratios ranged in value from 4.4 (date my sister) to 16.9 (open-minded). In Experiment II, only dominated discussion and opinionated were not significant. The $F$ ratios for the 18 significant measures ranged in value from 5.0 (presented clearly) to 57.2 (open-minded). In Experiment III, dominated discussion, value of contribution, and opinionated were not significant. The $F$ ratios for the 17 significant measures ranged in value from 5.4 (value of contribution, and relaxed) to 84.8 
(share dorm room). Clearly, the belief effects were pervasive and powerful.

The type of Ss (pro-anti) interacted with belief similarity on four items each in Experiments I and II and one item in Experiment III. However, the items that showed this effect differed across the three experiments and were not particularly informative. The triple interaction was significant for two items in Experiment I and three items in Experiment II, but no consistent patterns emerged for these few effects.

\section{Effects of Race}

Information pertaining to race effects was available in the main effect of race of actors, Race of Actors by $\mathrm{S}$ Type, Race of Actors by Belief Similarity-Dissimilarity, and the triple interaction (the latter was noted above) There were a few main effects of race on several measures across the three experiments, but they were not very consistent. In Experiment I, whites were rated as presenting their position more clearly and dominating the discussion more than blacks and the latter were rated as more open-minded. On the social distance item "date my sister," whites received more favorable ratings than blacks. In Experiment II, whites were rated more intelligent and informed than blacks, but blacks were more preferred as next-door neighbors.

There were six significant main effects of race for females in Experiment III, and they were all in favor of black actors. Blacks were liked better, perceived as more friendly, relaxed, and courteous, were less opinionated, and dominated the discussion less than whites.

The Race of Actors by S Type was not significant on any measure in any of the three experiments. The Race of Actors by Belief Similarity-Dissimilarity was significant on five measures in Experiment II and four in Experiment III. These effects are shown in Table 2 by a star in the column labeled "experiment." Inspection of the rows that are starred reveals an interesting effect. In all cases except the item "date my sister," the interaction was primarily due to the considerably lower ratings for dissimilar whites than for dissimilar blacks. The differences between similar whites and similar blacks were generally small and nonsignificant. This pattern of means suggests a "renegade effect." Blacks are expected to differ to some extent. However, the same differences in whites increased rejection. These effects were not very general, however, since they were restricted entirely to Experiments II and III.

In addition to the effects noted above, there was a significant main effect of type of Ss (pro- or anti-ROTC) on 10 measures in Experiment I. In every case, anti-ROTC Ss rated the actors more favorably than did pro-ROTC Ss. However, no conclusions were drawn. because there was only one such effect in Experiment II and none in Experiment 111.

\section{DISCUSSION}

The results of all three experiments strongly supported Rokeach, Smith, and Evans' (1960) theory. Similar confederates were more preferred on a variety of measures. These results strongly confirm previous findings. At the same time, the few race effects were not consistent over the three experiments and were as likely to favor blacks as whites. The notion that (a) a high degree of ego involvement via direct participation in the discussion, plus (b) privacy in making the ratings would yield race prejudice effects was not confirmed. It seemed clear that the situation was a powerful one for Ss and had about as much impact as one could reasonably create in a psychological experiment. In addition, the sessions were quite realistic. The Ss thought that the confederates were other students just like themselves, and the issues were quite meaningful and relevant for them. Indeed, many Ss indicated that it was too bad that similar discussion sessions could not be held on a regular basis in order to promote communication and understanding among students. Thus, it seems clear that the lack of strong race effects was not due to lack of impact, importance, or relevance of the issues to Ss' lives

It also seems unlikely that lack of race effects can be attributed to the nature of the measurement. Great care was taken to avoid problems such as those in the Rokeach and Mezei (1966) study. The nature of the cover story and the privacy for the ratings (including a manila envelope to put the rating booklet in) should have allowed honest responding.

With respect to racial effects, the "renegade effect" was intriguing. Although this effect did not occur on a great many items, it has been reported before (Hendrick \& Hawkins, 1969; Byrne \& Wong, 1962). One interpretation is that allowances are made for dissimilar outgroup members (Byrne \& Wong, 1962). However, comparisons of the white and black dissimilar means in Table 2 in an experiment which showed the effect for a given measure with an experiment which did not show the effect indicates that the effect was largely due to rejection of dissimilar whites. Thus, the effect may be properly dubbed a renegade effect. It is presently unclear as to what combinations of variables are necessary to elicit this effect.

At this point, it is reasonable to wonder what one may conclude concerning the race-belief issue. That belief prejudice exists is now well founded. Perhaps the most intriguing aspect of this research tradition is not that belief is more powerful than race, but that so few race effects exist at all. It seems clear now that simply increasing the power and realism of the experimental situation does not increase the number of race prejudice effects. Lack of such effects are now so numerous that one is tempted to accept the null hypothesis and 
conclude that college students are remarkably free of race prejudice.

Such a conclusion may be premature, however. Prejudice toward outgroups might be viewed as a set of beliefs and feelings directed not at specific individuals but at a concept-namely, the stereotypical views that one holds toward the outgroup. The expression of prejudiced feelings may require the direct activation of the outgroup concept. Further, it may be mistaken to conclude that direct contact or interaction with outgroup members will necessarily activate prejudiced feelings. Discussion of the outgroup stereotype directly may be a much more powerful elicitor of negative attitudes than actual contact. Recent work in our laboratory indicates that this view may have some validity. Ss were selected who were either high or low in prejudice on an attitude questionnaire. They then observed a taped discussion (as in Hendrick, Bixenstine, \& Hawkins, 1971) between two black and two white actors. The focus of the discussion was race per se. Preliminary analyses suggest that under these conditions, Ss initially high in prejudice discriminated against blacks in favor of whites. However, Ss initially low in prejudice discriminated against whites in favor of blacks. Thus, both positive and negative prejudice effects were obtained. These results indicate that a prejudiced attitude is elicited by and directed toward a concept of race rather than toward persons. When the concept is not activated, even highly prejudiced individuals (as measured by an attitude scale) may engage in a wide variety of interactions with outgroup members without any overt signs of hostility or behavioral discrimination, and indeed perhaps without any strong internal negative feelings at all.

\section{REFERENCES}

Aronson, E., \& Carlsmith, J. M. Experimentation in social psychology. In G. Lindzey and E. Aronson (Eds.), The handbook of social psychology: Vol. 2. (2nd ed.) Research methods. Cambridge, Mass: Addison-Wesley, 1968. Pp. 1-79.

Byrne, D. Attitudes and attraction. In L. Berkowitz (Ed.), Adrances in experimental social psychologi: Vol. 4. New York: Academic Press, 1969.

Byrne, D., \& Wong, T. J. Racial prejudice. interpersonal attraction, and assumed dissimilarity of attitudes. Journal of Abnormal \& Social Psychology, 1962, 65, 246-253.

Campbell, D. T. Prospective: Artifact and control. In R. Rosenthal and R. L. Rosnow (Eds.), Artifact in behavioral research. New York: Academic Press, 1969.

Hendrick, C., Bixenstine, V. E., \& Hawkins, G. Race versus belief similarity as determinants of attraction: A search for a fair test. Journal of Personality \& Social Psychology, 1971, 17, 250-258.

Hendrick, C, \& Hawkins, G. Race and belief similarity as determinants of attraction. Perceptual \& Motor Skills, 1969, $29,710$.

Hendrick, C., Stikes, C. S., \& Murray, E. J. Race versus belief similarity as determinants of attraction in a live interaction setting. Journal of Experimental Research in Personality, in press.

Rokeach, M. Belief versus race as determinants of social distance: Comments on Triandis' paper. Journal of Abnormal \& Social Psychology, 1961, 62, 187-188.

Rokeach, M., \& Mezei, L. Race and shared belief as factors in social choice. Science, 1966, 151, 167-172.

Rokeach, M., Smith, P., \& Evans, R. Two kinds of prejudice or one? In M. Rokeach (Ed.), The open and closed mind. New York: Basic Books, 1960.

Sears, D. O., \& Abeles, R. P. Attitudes and opinions. Annual Review of Psychology, 1969, 20, 253-288.

Triandis, H. A note on Rokeach's theory of prejudice. Journal of Abnormal \& Social Psychology, 1961, 62, 184-186.

\section{NOTE}

1. The authors are indebted to Frank Butler, James McGarry, Eric Phelps, and Gregory Simpson for serving as confederates in Experiments $I$ and II and to Sandra Davis, Evelyn McMichael, Donna Payne, and Kathy Soby for serving in Experiment III. revision received October 16. 1972.) 